\title{
Interferon synthesis by human colostral leucocytes
}

\author{
J. W. M. LAWTON, K. F. SHORTRIDGE, ROSAMUND L. C. WONG, AND M. H. NG
}

University of Hong Kong

SUMMARY The antiviral potential of human colostral leucocytes was assessed by their capacity to produce interferon. Leucocytes cultured from colostrum were stimulated by mitogens or Newcastle disease virus (NDV) to produce interferon which, by metabolic and physicochemical criteria, corresponded to normal human leucocyte interferon. Prepartum cells produced higher levels than postpartum cells. Colostral cells were less efficient producers than blood leucocytes.

Human colostrum and breast milk contain inhibitors for a variety of viruses (Sabin and Fieldsteel, 1962; Shortridge et al., 1974; Matthews et al., 1976). The presence of interferon in human colostrum or milk has not been conclusively demonstrated, although colostral leucocytes are known to be able to synthesise interferon-like material in response to stimulation (Emödi and Just, 1974; Lawton and Shortridge, 1977).

In view of the current interest in the function of these cells and their possible contribution to neonatal defences in breast feeding, we have investigated further the capacity of colostral cells to synthesise interferon when stimulated by mitogens and inactivated NDV. We also report the results of our characterisation of this substance.

\section{Materials and methods}

Preparation and culture of colostral cells. Colostrum samples were obtained from 26 women, mainly Chinese, by manual expression into sterile plastic universal bottles. 11 samples were prepartum and 15 were 2 to 5 days postpartum. Samples were diluted 1:1 in Hank's balanced salt solution (HBSS), centrifuged at $110 \times g$ for $10 \mathrm{~min}$ and the pellet washed twice in HBSS before counting the cells in a haemocytometer. Total cell counts in colostrum ranged from 0.6 to $11 \times 10^{9} / 1\left(600\right.$ to $\left.11000 / \mathrm{mm}^{3}\right)$ mean $3 \cdot 37 \times 10^{9} / 1\left(3370 / \mathrm{mm}^{3}\right)$. Differential counts

University of Hong Kong

Department of Pathology

J. W. M. LAWTON, senior lecturer

Department of Microbiology

K. F. SHORTRIDGE, reader

M. H. NG, senior lecturer

Department of Obstetrics and Gynaecology

ROSAMUND L. C. WONG, lecturer were performed on stained cytocentrifuge preparations; macrophages made up 11-94\% (mean 57\%), polymorphonuclear leucocytes(PMNs) 2-87\%(mean $33 \%$ ), and lymphocytes $1-39 \%$ (mean $9.6 \%$ ).

After counting, the cells were resuspended at a concentration of $2 \times 10^{9}$ cells $/ 1\left(2000 / \mathrm{mm}^{3}\right)$ in leucocyte growth medium (LGM) comprising RPMI-1640 (Gibco) supplemented with $20 \%$ heatinactivated human $A B$ serum, glutamine $2 \mathrm{mmol} / \mathrm{l}$, penicillin $100 \mathrm{U} / \mathrm{ml}$, and streptomycin $100 \mu \mathrm{g} / \mathrm{ml}$. One $\mathrm{ml}$ volume of cell suspension was dispensed into Nunc tissue culture tubes; the total number of cells obtained from the colostrum sample (usually about $15 \times 10^{9} / 1\left(15000 / \mathrm{mm}^{3}\right)$ ) limited the number of replicate cultures that could be performed. Mitogens known to stimulate leucocyte interferon synthesis were added to the cultures in predetermined optimal doses; PHA-P (Difco) $5 \mu \mathrm{l} / \mathrm{ml}$, Conconavolin-A (Sigma) $40 \mu \mathrm{g} / \mathrm{ml}$. Cells were also preincubated for $30 \mathrm{~min}$ with an optimal dilution of a lentogenic (avirulent) strain of NDV (D2/75) and then washed 3 times before resuspending in LGM for culture. Each experiment included an unstimulated control culture. Cultures were incubated at $37^{\circ} \mathrm{C}$ for 72 hours. The supernatants were harvested and replicate supernatants pooled before being assayed for interferon activity. Supernatants were routinely stored frozen at $-20^{\circ} \mathrm{C}$, but for periods of less than 24 hours they were held at $4^{\circ} \mathrm{C}$.

Interferon assay. The assay was based on that of Havell and Vilček (1972) using human diploid foreskin fibroblasts in Linbro micro T/C plates. Fibroblasts were challenged with vesicular stomatitis virus (VSV) after 24-hour exposure to culture supernatants and the titre of interferon was expressed as the reciprocal of the highest protective dilution. A standard interferon preparation (13 $000 \mathrm{NIH}$ units/ 
$\mathrm{ml}$ ) consistently gave a titre of 50000 . Samples were titred at trebling dilutions beginning at $1 / 5$ and assayed in duplicate.

Dialysis of samples before assay did not alter the interferon titre but it did reduce the cytotoxic effect on fibroblasts which was sometimes observed at low dilutions $(1 / 5$ or $1 / 15)$. Therefore predialysis of samples at $\mathrm{pH} 2$ was adopted as standard procedure (see below, acid dialysis). Samples containing Con-A tended to be more toxic to the fibroblasts at low dilutions and this effect was not removed by dialysis. Consequently Con-A was often omitted and Con-A supernatants were not used in the characterisation studies even though it tended to induce higher interferon levels than PHA or NDV.

Comparison of colostral cells and autologous blood leucocytes. In 7 cases autologous blood leucocytes were cultured in parallel with the colostral cells to compare their capacities to synthesise interferon-like substances in vitro.

Blood lymphocytes were separated from heparinised blood over Ficoll/Hypaque, washed 3 times in BSS, counted and resuspended in LGM at $2 \times 10^{9}$ cells $/ 1\left(2000 / \mathrm{mm}^{3}\right)$. The suspensions contained 5$15 \%$ monocytes. The blood mononuclears were stimulated with PHA and NDV as described for colostral cells. After 72 hours' incubation the supernatant was harvested and assayed for interferon activity.

Characterisation studies. High titre supernatants of PHA- or NDV-stimulated cultures were pooled and studied as follows:

\section{Metabolic characterisation}

This was based on the fact that the protective effect of interferon requires intact mechanisms of RNA and protein synthesis in the cells on which protection is to be conferred ( $\mathrm{Ng}$ and Vilček, 1972).

To inhibit RNA synthesis fibroblasts were pretreated with actinomycin $D(0.5$ and $1.0 \mu \mathrm{g} / \mathrm{ml}$ in culture medium) for $30 \mathrm{~min}$ at $37^{\circ} \mathrm{C}$ then washed 3 times in HBSS before adding the pooled supernatant. To inhibit protein synthesis cycloheximide was diluted in culture medium to $100 \mu \mathrm{g} / \mathrm{ml}$ and this medium was used as diluent for the pooled supernatant. Cells exposed to cycloheximide were washed 3 times in HBSS before virus challenge. Supernatant was also assayed on control cells not exposed to metabolic inhibitor. Each group included appropriate positive and negative controls for virus cytopathic effect.

\section{Physiocochemical characterisation}

Supernatant aliquots were treated as described below before assay.
Acid dialysis. Supernatants were dialysed against $0 \cdot 1 \mathrm{~mol} / 1 \mathrm{KCl}, \mathrm{pH} 2$, at $4^{\circ} \mathrm{C}$ for 18 hours, then against phosphate buffered saline (PBS), pH 7.4, for 4 hours. Control supernatants were dialysed for 22 hours against PBS only.

Freeze-thaw, heat, and trypsinisation. Respective aliquots were frozen to $-70^{\circ} \mathrm{C}$ and thawed 5 times, heated to $56^{\circ} \mathrm{C}$ for $30 \mathrm{~min}$, or incubated in the presence of trypsin $(1.25 \mathrm{mg} / \mathrm{ml})$ at $37^{\circ} \mathrm{C}$ for 5 hours. A control aliquot was kept at $4^{\circ} \mathrm{C}$.

Detection of sialic acid residues. Pooled supernatant of known titre was applied to a column of immobilised neuraminidase at $\mathrm{pH} 4 \cdot 5$. The column was developed by elution with $0.1 \mathrm{~mol} / 1 /$ acetate buffer in $0.5 \mathrm{~mol} / 1$ $\mathrm{NaCl}, \mathrm{pH} 4 \cdot 5$, followed by $0.1 \mathrm{~mol} / 1$ bicarbonate in $0.5 \mathrm{~mol} / 1 \mathrm{NaCl}, \mathrm{pH} 9.0$. The eluted protein peaks (OD $280 \mathrm{~nm}$ ) were collected and tested for interferon activity (Fung and $\mathrm{Ng}, 1978$ ).

In the interferon characterisation experiments supernatants were titred at trebling dilutions.

\section{Results}

Table 1 shows the geometric mean titres of interferon in the colostral cell cultures. Two PHA supernatants $(>135)$ were not titred to the endpoint; these were taken as 135 and all negative samples $(<5)$ were taken as 1 for purposes of calculation. The highest interferon titre obtained was 640 in a Con-A stimulated culture from a prepartum sample. The combined results (pre- and postpartum) show that Con-A gave the highest mean interferon activity, while NDV, although less efficient than Con-A, was a more efficient inducer than PHA. All unstimulated control cultures were negative for interferon activity (titre $<5$ ).

Prepartum colostral cells produced higher interferon levels than postpartum cells; this was so for

Table 1 Interferon activity in colostral cell culture supernatants

\begin{tabular}{lllll}
\hline & $\begin{array}{l}\text { PHA } \\
\text { stimulated }\end{array}$ & $\begin{array}{l}\text { Con-A } \\
\text { stimulated }\end{array}$ & $\begin{array}{l}\text { NDV } \\
\text { stimulated }\end{array}$ & $\begin{array}{l}* \text { All } \\
\text { inducers }\end{array}$ \\
\hline Prepartum & $11(1-320)$ & $59(1-640)$ & $38(15-135)$ & $21(1-640)$ \\
& $\mathrm{n}=11$ & $\mathrm{n}=3$ & $\mathrm{n}=7$ & $\mathrm{n}=21$ \\
Postpartum & $7.6(1-135)$ & $24(1-135)$ & $12(1-45)$ & $11(1-135)$ \\
& $\mathrm{n}=15$ & $\mathrm{n}=6$ & $\mathrm{n}=8$ & $\mathrm{n}=29$ \\
All cultures & $9 \cdot 7(1-320)$ & $32(1-640)$ & $19(1-135)$ & \\
$\begin{array}{ll}\text { (pre- and post- } \\
\text { partum) }\end{array}$ & $\mathrm{n}=26$ & $\mathrm{n}=9$ & $\mathrm{n}=15$ & \\
\hline
\end{tabular}

The results are expressed as geometric mean titres of 72-hour culture supernatants with titre ranges in parentheses. Differences between mean titres of pre- and postpartum cultures did not reach significance at the $5 \%$ level (2-tailed Student's $t$ test). Unstimulated control cultures were negative (titre $<5$ ) in all experiments.

*Pooled data for the 3 inducers. 
each inducer but even when data were pooled (Table 1) the difference was not significant at the $5 \%$ level $(0 \cdot 15>P>0 \cdot 1)$. This difference could not be explained by the relative proportions of cell types in the cultures; the mean percentages of macrophages, lymphocytes, and PMNs in prepartum and postpartum colostrum were very similar and the overall data showed no clear correlation between interferon titres and the proportions of cell types in the original culture inocula.

Colostral cells and autologous blood leucocytes. The geometric mean titres of interferon from these paired cultures are set out in Table 2. The capacity of blood mononuclears to synthesise interferon in response to NDV stimulation was significantly higher than that of colostral cells $(P<0.025)$, whereas the difference in response to PHA did not reach a level of significance $(\mathrm{P}>0 \cdot 15)$.

Table 2 also shows that NDV was clearly a more efficient inducer of interferon in blood leucocytes than was PHA (ratio, 8:5:1), whereas colostral cells demonstrated little difference in response to these two inducers.

Interferon characterisation. The results of the characterisation studies are summarised in Table 3. Inhibitors of RNA and protein synthesis both abrogated the protection of fibroblasts by the culture supernatants, consistent with the protective effect being due to interferon.

Activity was not dialysable; it was stable at $\mathrm{pH} 2$ and destroyed by trypsin. PHA-induced activity was

Table 2 Interferon activity in colostral cell and autologous blood leucocyte cultures

$\left.\left.\begin{array}{lll}\hline & P H A \text {-stimulated } & \text { NDV-stimulated } \\ \hline \text { Colostral cells } & 16 \\ (1-135) \\ \begin{array}{c}\text { Autologous blood } \\ \text { leucocytes }\end{array} & 10 \\ (1-45)\end{array}\right\} \begin{array}{l}\begin{array}{l}18 \\ (5-45) \\ (\mathrm{n}=0 \cdot 15\end{array} \\ \begin{array}{l}85 \\ (15-415)\end{array}\end{array}\right\} \begin{aligned} & \mathrm{P}<0.025 \\ & (\mathrm{n}=6)\end{aligned}$

The results are expressed as geometric mean titres of 72 -hour culture supernatants with titre ranges in parentheses. $P$ values were computed by the Student's $t$ test for correlated data. Unstimulated control cultures were negative (titre $<5$ ) in all experiments. stable to freeze-thaw and relatively heat stable. On the other hand, NDV-induced activity was relatively freeze-thaw stable and heat labile.

Interferon activity induced by NDV bound to a column of immobilised neuraminidase at acid $\mathrm{pH}$ via its $\mathrm{N}$-acetyl-neuraminic acid residues and could be recovered essentially without loss of activity by elution at $\mathrm{pH} 9 \cdot 0$.

\section{Discussion}

Recent studies have shown that leucocytes in colostrum may play an important role in transferring specific and nonspecific host resistance factors to the neonate (Murillo and Goldman, 1970; Ahlstedt et al. 1975; Parmely et al., 1976; Pitt et al., 1977; Schlesinger and Covelli, 1977). Our results confirm that colostral leucocytes can synthesise interferon under appropriate conditions and that their capacity to do so is comparable with that of blood leucocytes (Emödi and Just, 1974).

Interferon protects a cell by first inducing the synthesis of an antiviral protein (Joklik, 1977) and this process is dependent on intact mechanisms of RNA and protein synthesis ( $\mathrm{Ng}$ and Vilček, 1972). It was found that the antiviral effect observed in our experiments was dependent on (1) pretreatment of cultures with supernatant, and (2) intact macromolecular synthesis of the fibroblasts. It was further shown that the antiviral substance was nondialysable, resistant to treatment with acid, stable to freeze-thaw, destroyed by trypsin, and it appeared to have sialic acid residues which bound it to immobilised neuraminidase. These are all known properties of interferon.

Surprisingly, this interferon was unlike classical human leucocyte interferon (type I) in being relatively heat labile. Haahr et al. (1976) showed that the presence of fully differentiated macrophages resulted in the production of heat-labile (type II) interferon by human lymphocytes. Therefore the high proportion of mature macrophages in colostral leucocyte cultures may account for heat-labile interferon synthesis. Because our colostral cells contained a mixture of lymphocytes (usually $<10 \%$ ) and macrophages, it is difficult to draw any conclusions about

Table 3 Metabolic and physicochemical characterisation of interferon activity

\begin{tabular}{|c|c|c|c|c|c|c|c|}
\hline & $\begin{array}{l}\text { Actinomycin-D } \\
0.5 \mu \mathrm{g} / \mathrm{ml}\end{array}$ & $\begin{array}{l}\text { Cycloheximide } \\
100 \mathrm{mg} / \mathrm{ml}\end{array}$ & $\begin{array}{l}\text { Dialysis } \\
\text { pH } 2\end{array}$ & Freeze-thaw & Heat & Trypsin & $\begin{array}{l}\text { Sialic acid } \\
\text { residues }\end{array}$ \\
\hline $\begin{array}{l}\text { PHA-induced } \\
\text { NDV-induced }\end{array}$ & $\begin{array}{l}\text { Not done } \\
+\end{array}$ & $\begin{array}{l}+ \\
+\end{array}$ & - & $\overline{ \pm}$ & $\begin{array}{l} \pm \\
+\end{array}$ & $\begin{array}{l}+ \\
+\end{array}$ & $\begin{array}{l}\text { Not done } \\
\text { Present }\end{array}$ \\
\hline
\end{tabular}

Supernatants titred at trebling dilutions.

- Denotes stability; \pm denotes reduction in activity of one dilution; + denotes reduction in activity of more than one dilution (or abrogation of interferon effect by metabolic inhibitors). 
the principal cell of origin of the interferon activity. Human interferon is known to be heterogeneous with respect to the cell of origin and to the type of inducer (Vilcek et al., 1977); it is likely, therefore, that the active material in our cultures represented a mixture of 'interferons'.

It is of interest that prepartum colostrum leucocytes showed a greater capacity to produce interferon than did postpartum cells. This difference could not be related to the very small differences in proportions of cell types in the cultures; the reason for it remains unknown.

Emödi and Just (1974) and Matthews et al. (1976) were unable to detect free interferon-like activity in human colostrum or breast milk. We have been able to detect interferon-like activity in a small proportion of the samples of colostrum and breast milk which we have tested (unpublished observations) and work is in progress to characterise it. It is not yet clear whether this activity is related to infection in the mother.

The important implication of our findings is that since colostral leucocytes under appropriate conditions can produce interferon, they may thereby confer on the suckling infant protection against viral infection.

We thank Miss Chan Kwan Lai and Miss L. Y. Hu for their excellent technical assistance.

\section{References}

Ahlstedt, S., Carlsson, B., Hanson, L. A., and Goldblum, R. M. (1975). Antibody production by human colostral cells. I. Immunoglobulin class, specificity, and quantity. Scandinavian Journal of Immunology, 4, 535-539

Emödi, G., and Just, M. (1974). Interferon production by lymphocytes in human milk. Scandinavian Journal of Immunology, 3, 157-160.

Fung, K. P., and Ng, M. H. (1978). Purification of human diploid fibroblast interferon by immobilised neuraminidase. Archives of Virology, 56, 1-6.
Haahr, S., Rasmussen, L., and Merigan, T. C. (1976). Lymphocyte transformation and interferon production in human mononuclear cell microcultures for assay of cellular immunity to herpes simplex virus. Infection and Immunity, 14, 47-54.

Havell, E., and Vilcek, J. (1972). Production of high-titered interferon in cultures of human diploid cells. Antimicrobial Agents and Chemotherapy, 2, 476-484.

Joklik, W. K. (1977). The mechanism of action of interferon. Annals of the New York Academy of Sciences, 284, 711-716.

Lawton, J. W. M., and Shortridge, K. F. (1977). Letter: Protective factors in human breast milk and colostrum. Lancet, 1, 253.

Matthews, T. H. J., Nair, C. D. G., Lawrence, M. K., and Tyrrell, D. A. J. (1976). Antiviral activity in milk of possible clinical importance. Lancet, 2, 1387-1389.

Murillo, G. J., and Goldman, A. S. (1970). The cells of human colostrum. II. Synthesis of IgA and $\beta I C$. Pediatric Research, 4, 71-75.

$\mathrm{Ng}$, M. H., and Vilček, J. (1972). Interferons: physicochemical properties and control of cellular synthesis. Advances in Protein Chemistry, 26, 173-241.

Parmely, M. J., Beer, A. E., and Billingham, R. E. (1976). In vitro studies on the T-lymphocyte population of human milk. Journal of Experimental Medicine, 144, 358-370.

Pitt, J., Barlow, B., and Heird, W. C. (1977). Protection against experimental necrotising enterocolitis by maternal milk. I. Role of milk leukocytes. Pediatric Research, 11, 906-909.

Sabin, A. B., and Fieldsteel, A. H. (1962). Antipoliomyelitis activity of human and bovine colostrum and milk. Pediatrics, 29, 105-115.

Schlesinger, J. J., and Covelli, H. D. (1977). Evidence for transmission of lymphocyte responses to tuberculin by breast-feeding. Lancet, 2, 529-532.

Shortridge, K. F., Ng, M. H., and Wong, R. L. C. (1974). Respiratory virus inhibitors in the colostrum of Chinese donors. Journal of Tropical Medicine and Hygiene, 77, 94-102.

Vilček, J., Havell, E. A., and Yamazaki, S. (1977). Antigenic, physicochemical, and biologic characterisation of human interferons. Annals of the New York Academy of Sciences, 284, 703-710.

Correspondence to Dr J. W. M. Lawton, Department of Pathology, University of Hong Kong, Queen Mary Hospital Compound, Hong Kong.

Received 6 June 1978 